DOI $10.15593 / 2224-9354 / 2017.2 .5$

УДК 316.334 .56

\author{
А.С. Зуйкина, Ю.Г. Шилов
}

\title{
ДИФФЕРЕНЦИАЦИЯ СТРАТЕГИЙ \\ ОРГАНОВ МСУ ПЕРМИ В ОТНОШЕНИИ ПЕРЕВОЗЧИКОВ, ОБСЛУЖИВАЮЩИХ ГОРОДСКИЕ МАРШРУТЫ
}

\begin{abstract}
В статье раскрываются особенности взаимодействия органов местного самоуправления (МСУ) Перми и перевозчиков, обслуживающих городские общественные маршруты. В функции муниципальной власти в данной сфрере входит определение маршрутов и графриков движения транспорта, оповещение об изменениях в его работе, проведение конкурсов на обслуживание маршрутов, субсидирование деятельности перевозчиков. Закономерным представляются различия в характере отношений органов МСУ, с одной стороны, к муниципальным, с другой - к частным перевозчикам. Прежде всего, в отношении к первым поднимаются вопросы финансовой помощи. Именно последних касаются процедуры вхождения в сферу обслуживания городских маршрутов через участие в конкурсах. В первой части статьи авторами обозначаются основные этапы развития муниципальной политики Перми в ссрере транспорта в 2000-е годы. До начала 2000-х годов в Перми действовала маршрутная сеть, установленная еще в советский период. Первое значительное ее обновление произошло в 2004 году с созданием Единой сети регулярных городских маршрутов пассажирского транспорта. Модернизация транспортной отрасли в 2006 году характеризовалась фактической ликвидацией муниципального автобусного парка, внедрением конкурсов на право обслуживания маршрута. Соответственно возросло количество участников со стороны частных перевозчиков. Авторами выявлена специфика стратегий местной власти в отношении частных и муниципальных перевозчиков, а также отдельных представителей «частного сектора». Согласно результатам исследования, установленные в сфере общественного транспорта формальные институты взаимодействия зачастую подменяются неформальными договоренностями и практиками. Эмпирическими данными для исследования выступают материалы региональных СМИ, а также статистические данные по различным параметрам обслуживания частными перевозчиками автобусных маршрутов Перми.

Ключевые слова: органы местного самоуправления, общественный транспорт, муниципальные перевозчики, частные перевозчики, стратегии муниципальной власти в отношении перевозчиков.
\end{abstract}

Муниципальная власть выступает регулятором отношений между пассажирами и перевозчиками: определяет маршруты и графики движения транспорта, оповещает об изменениях в его работе, проводит конкурсы на обслуживание маршрутов. В сферу взаимодействия по данным вопросам вступает большое количество субъектов, обладающих разными юридическими статусами. Прежде всего необходимо выделить частных и муниципальных перевозчиков. Автобусные маршруты поделены между частными предпринимателями, единственным исключением является автобусный маршрут № 62,

(c) Зуйкина А.С., Шилов Ю.Г., 2017

Зуйкина Анна Сергеевна - канд. полит. наук, доцент кафедры государственного управления и истории, ФГБОУ ВО «Пермский национальный исследовательский политехнический университет», e-mail: votinova@inbox.ru.

Шилов Юрий Геннадьевич - бакалавр государственного и муниципального управления, ФГБОУ ВО «Пермский национальный исследовательский политехнический университет», e-mail: yury.schilov2014@yandex.ru. 
который обслуживается МУП «ПермГорЭлектроТранс». Последний также осуществляет перевозки пассажиров на трамваях и троллейбусах. Таким образом, в сфере организации автобусного транспорта органов МСУ Перми выстраивают взаимодействия преимущественно с частными перевозчиками, в сфере организации электротранспорта - с муниципальными. Безусловно, стратегии органов власти в отношении разных групп участников различны. Кроме того, представляется неоднозначным и характер взаимодействия муниципальной власти и отдельных представителей частного сектора.

Таким образом, цель данного исследования заключается в выявлении стратегий органов МСУ Перми в отношении разных участников, определении опосредующих их факторов (причин), а также эффектов (результатов применения стратегий). Эмпирической базой исследования выступают материалы СМИ за 2000-2016 годы (Business-Class, КоммерсантЪ), а также статистические данные по различным параметрам обслуживания частными перевозчиками автобусных маршрутов Перми.

Динамика муниципальной политики Перми в сфере общественного mранспорта в 2000-е zоды. На протяжении 2000-х годов транспортная сфера Перми неоднократно подвергалась реформированию. Объектом управленческих инициатив, как правило, становилась маршрутная сеть. Ее изменения связаны с увеличением пассажиропотока, налаживанием и улучшением связи отдаленных микрорайонов с центром города, достижением большей транспортной доступности населения. В этот период можно выделить несколько этапов реформирования городской транспортной сферы.

До начала 2000-х годов в Перми действовала маршрутная сеть, установленная еще в советский период. Ее изменения осуществлялись практически ежегодно, но не носили принципиального характера. Первое значительное ее обновление произошло в 2004 году. Решением администрации Перми создается Единая сеть регулярных городских маршрутов пассажирского транспорта города в целях обеспечения безопасности перевозок, повышения культуры и качества обслуживания пассажиров, создания цивилизованного рынка транспортных услуг, упорядочивания процедуры открытия регулярных автобусных маршрутов [1]. В связи с массовой застройкой отдаленных микрорайонов (Левшино, Пролетарский и т.д.) появляются новые автобусные маршруты.

Модернизация транспортной отрасли в 2006 году [2] характеризуется фактической ликвидацией автобусного муниципального парка (ныне действующий муниципальный парк обладает малым количеством подвижного состава [3]), внедрением конкурсов на право обслуживания маршрута, распространением льготного проезда на частные автобусы, приведением маршрутов в «общий вид» (а именно: на всех автобусах были установлены маршрутоуказатели нового образца с черным шрифтом на желтом фоне).

Согласно действующему на сегодня Положению об организации пассажирских перевозок автомобильным транспортом общего пользования на 
маршрутах регулярных перевозок Перми, утвержденному решением Пермской городской думы от 29.06.2006 г. № 138, обслуживание маршрутов регулярных перевозок города автобусами осуществляется посредством проведения конкурсной процедуры на выбор перевозчика. Контроль за проведением конкурсных процедур, качеством обслуживания маршрутов осуществляется Департаментом дорог и транспорта города Перми.

Отметим, в результате реформирования городской транспортной системы монополизации отрасли автобусных пассажирских перевозок не произошло, так как в процесс обслуживания автобусных маршрутов включилось более 30 «игроков».

В 2009 году под влиянием перевозчиков, организовавших серию забастовок, власти Перми принимают решение о перераспределении маршрутов. Суть конфликта заключалась в отказе некоторых перевозчиков провозить льготные категории граждан по действующим тарифам и их требованиях либо повышения стоимости проезда, либо увеличения объема субсидирования со стороны администрации города [4]. В результате городские власти расторгают договоры с бастующими перевозчиками и, с целью ограничения рисков наступления транспортного коллапса, допускают к работе на маршрутах других перевозчиков.

Наконец, ключевым муниципальным решением, определяющим существующие сегодня взаимодействия в сфере общественного транспорта Перми, стало создание в 2015 году Единой маршрутной сети [5], целью которой была оптимизация маршрутной сети городского пассажирского транспорта. Согласно Постановлению местной администрации № 796 от 30.10.2014 г. «Об утверждении Единой маршрутной сети городского пассажирского транспорта общего пользования города Перми» (с изменениями на 21.05.2015 г.), в качестве задач реформы органами власти провозглашены приоритет электротранспорта и исключение дублирования автобусных маршрутов.

Необходимость достижения первого направления обосновывалась экологичностью трамваев и троллейбусов. Однако можно отметить ряд обстоятельств, которые ставят под вопрос его приоритетность, а именно: сеть электротранспорта разбросана по Перми неравномерно и затрагивает лишь некоторые районы города, другой берег Камы остается неохваченным. Также стоит отметить неудовлетворительное состояние трамвайных путей и большой возраст подвижного состава, несмотря на обновление парка в 2011 году. В связи с этим основное внимание муниципальных властей остается направленным на автобусный транспорт.

Что касается второго направления по исключению дублирования автобусных маршрутов, его не удалось реализовать в полной мере ${ }^{1}$.

${ }^{1}$ К примеру, сохранен автобусный маршрут № 54, в большинстве своем дублирующий маршрут № 37; маршрут № 66 был частично изменен и повторяет автобусный маршрут № 74 [6].

PNRPU Sociology and Economics Bulletin. 2017. No. 2 
Последствием изменения маршрутной сети стало увеличение числа нелегалов. Эту «недобросовестную» группу участников пополнили: 1) перевозчики, деятельность которых формально прекращена решениями муниципальной власти о ликвидации дублирующих маршрутов (№ 11 и 30); 2) перевозчики, проигравшие конкурсы на обслуживание автобусных маршрутов.

Стратегии органов МСУ Перми в отночении частных и муниципальных перевозчиков. Одно из оснований различия стратегий местной власти в отношении организаций, обслуживающих сферу пассажирских перевозок, связано с юридическим статусом последних. Материалы исследования свидетельствуют о реализации администрации Перми в отношении муниципальных перевозчиков (МУП «ПермГорЭлектроТранс») стратегий покровительства.

Согласно Единой маршрутной сети, введенной в действие в 2015 году, приоритетным видом транспорта является электрический, при этом его реальное значение для жителей в сравнении с автобусным транспортом значительно ниже [6]. Так, данный вид транспорта обслуживает всего 17 \% населения, несколько районов города и абсолютно не затрагивает районы, расположенные на другом берегу реки Камы [7]. Кроме того, отмечается дублирование многими троллейбусными маршрутами автобусных маршрутов, тогда как исключительную ценность троллейбусы имеют только для жителей одного м/p Крохалева. Изначально заложенный акцент производит соответствующие «правила игры» и линию поведения ключевого субъекта взаимодействий. «Покровительственное» отношение местной администрации к МУП «ПермГорЭлектроТранс» приводит к установлению властями разных «правил игры» в сфере общественного транспорта для «муниципалов» и «частников».

Во-первых, различия касаются требований к характеристикам подвижного состава (ПС), обслуживающего маршруты. Так, мост перед станцией Пермь I имеет ограничение по массе, поэтому на автобусном маршруте № 3, представляющем данный участок, работают частные перевозчики, используя автобусы малой вместимости (МВ). Однако этот участок также пересекает маршрут № 1, обслуживаемый троллейбусами большой вместимости, вес которых превышает допустимые нагрузки на мост. При этом никаких правоприменительных санкций к МУП администрация Перми не применяет.

Во-вторых, согласно материалам пермских СМИ, субсидии МУП «ПермГорЭлектроТранс» за провоз граждан и льготных категорий населения несоразмерно высоки и не соответствуют фактическому пассажиропотоку [8]. Муниципальный транспорт обслуживает часть районов левого берега, тогда как частные автобусные перевозчики обслуживают все районы Перми. При этом последние в сумме получают субсидии в несколько раз меньше [9]. Именно поэтому нередки случаи обращений перевозчиков в суды с требованием выплаты субсидий, а также их публичных попыток донести проблему до власти через СМИ и общественность [10].

«Особое» отношение органов власти к муниципальным перевозчикам негативно сказывается на качестве их деятельности. Так, у представителей 
муниципального транспорта отсутствуют стимулы для соблюдения графиков$^{2}$. Также крайне редко происходит обновление ПС электротранспорта ${ }^{3}$. Заметим, муниципальные нормативно-правовые акты, регулирующие частоту обновления ПС электротранспорта, на данный момент отсутствуют.

Дифференциация стратегий органов МСУ Перми в отночении частных перевозчиков. Частные перевозчики на автобусных маршрутах регулярных перевозок появились в Перми в середине 1990-х годов, и с каждым годом их число росло. До «бунта» перевозчиков в сентябре 2009 года в Перми работало по разным данным 100-130 «частников». В настоящий момент деятельность осуществляют чуть более 40 перевозчиков. Часть перевозчиков (четверть от общего числа) состоят в некоммерческих партнерствах (НП):

1) НП «Автолидер» (директор А.В. Богданов) включает ИП Богданов А.В. (ООО «А-ТУР-ТРАНС», ООО «Вираж», ООО «Сити-Бас») и ИП Новоселов О.В. (ИП Полежаев С.Л.);

2) НП «Единый союз перевозчиков» (далее - ЕСП) (директор М.Е. Ухватов), включает ИП Бабушкин М.Н. (ООО «Техстрой-Авто», ООО «АвтоТех») и ООО «СпецТрансАвто» (принадлежит Жуланову С.В.), последнему также подконтрольны ООО «Пермская Транспортная Компания», ООО «Сервис-Авто», ООО «Техстрой-Авто-Плюс», ООО «Транс-А», ООО «Транском»;

3) НП «Новый-Авто-Альянс» (директор А.М. Стерлягов), действует с 2012 года, его предшественник с 2009 года - НП «Автоальянс» (ИП Иванов В.А., ИП Караев С.Н, ИП Одинцов О.В.); в настоящий момент включает ИП Иванов В.А., ИП Караев С.Н.;

4) НП «Автоликон» (директор В.В. Поздеев), включает ИП Поздеев В.В., ИП Шадрин Н.Н., ИП Шушлебин В.И.

Роль отдельных частных перевозчиков в обслуживании автобусного транспорта Перми различна. Для ее оценки авторами проанализированы статистические данные по количеству графиков перевозчиков на маршрутах. В таблице и на рисунке 4 представлены результаты проведенного расчета, согласно которым

2 Ярким примером может служить автобусный маршрут № 62, движение которого беспорядочно, пропуск «кругов» - частое явление, особенно в вечернее время [7]. Предыдущий частный перевозчик в большинстве своем соблюдал расписание движения маршрута, пропуск «кругов» не фиксировался. Однако он проиграл конкурс по причине использования устаревшего подвижного состава [4].

${ }^{3}$ Несмотря на частичную замену устаревшего троллейбусного парка в 2010 году приобретено 46 новых троллейбусов - они быстро выходят из строя по причине низкого качества обслуживания. В 2011 году было приобретено 39 новых трамваев, однако из них на данный момент работает лишь 25. При этом можно встретить трамваи 1983-1990 годов выпуска.

${ }^{4}$ Составлено авторами на основании данных конкурсной документации на сайте администрации г. Перми, Реестра муниципальных маршрутов регулярных перевозок Перми, а также информации, представленной на интернет-портале «Автобусный транспорт. Объединенная фотогалерея. Западный Урал. Пермский край». 
наибольшее количество графиков на автобусных маршрутах принадлежит нескольким перевозчикам: ИП Караев С.Н. (12,5 \%), ИП Мирзамухаметов И.М. (11,2 \%), ИП Колодяжный А.П. (9,4 \%), ИП Иванов В.А. $(8,5 \%)$, ИП Богданов А.В. (6,9 \%), ИП Новоселов О.В. (5,3\%).

Распределение графиков обслуживания автобусного транспорта Перми между муниципальным и частными перевозчиками

\begin{tabular}{|c|c|c|c|}
\hline $\begin{array}{l}\text { № } \\
\text { ח/п }\end{array}$ & Перевозчик & $\begin{array}{l}\text { Суммарное количество } \\
\text { графиков у перевозчика }\end{array}$ & $\begin{array}{c}\text { Доля от общего } \\
\text { количества графиков, \% }\end{array}$ \\
\hline 1 & ИП Анисимов Е.Г. & 12 & 1,55 \\
\hline 2 & ИП Антипов А.А. & 7 & 0,90 \\
\hline 3 & ИП Аристов С.В. & 27 & 3,49 \\
\hline 4 & ООО «АРТ-Стиль» & 18 & 2,33 \\
\hline 5 & ИП Бабушкин М.Н. & 18 & 2,33 \\
\hline 6 & ИП Белозеров П.В. & 13 & 1,68 \\
\hline 7 & ИП Богданов А.В. & 53 & 6,85 \\
\hline 8 & ИП Жужгов И.Ю. & 24 & 3,10 \\
\hline 9 & ООО «Закамский автобус» & 37 & 4,78 \\
\hline 10 & ИП Иванов В.А & 66 & 8,53 \\
\hline 11 & ИП Изгагин С.А. & 1 & 0,13 \\
\hline 12 & ИП Камбур К.В. & 5 & 0,65 \\
\hline 13 & ИП Караев С.Н. & 97 & 12,53 \\
\hline 14 & ИП Кирсанов А.И. & 17 & 2,20 \\
\hline 15 & ИП Колодяжный А.П. & 73 & 9,43 \\
\hline 16 & ИП Коротаева А.А. & 6 & 0,78 \\
\hline 17 & ИП Костарев Г.М. & 4 & 0,52 \\
\hline 18 & ИП Красновский Е.В. & 13 & 1,68 \\
\hline 19 & ИП Мирзамухаметов И.М. & 87 & 11,24 \\
\hline 20 & ИП Михалев А.Г. & 1 & 0,13 \\
\hline 21 & ИП Морохина Л.В. & 5 & 0,65 \\
\hline 22 & ИП Новоселов О.В. & 41 & 5,30 \\
\hline 23 & ИП Окулова Г.Р. & 16 & 2,07 \\
\hline 24 & ИП Перевозчиков Ю.П. & 3 & 0,39 \\
\hline 25 & ООО «ПермьАвтоЛайн» & 14 & 1,81 \\
\hline 26 & ИП Рукк Т.В. & 4 & 0,52 \\
\hline 27 & ИП Русаков В.И. & 6 & 0,78 \\
\hline 28 & ООО «СпецТрансАвто» & 35 & 4,52 \\
\hline 29 & ИП Старков М.С. & 2 & 0,26 \\
\hline 30 & ИП Старков С.Н. & 15 & 1,94 \\
\hline 31 & ИП Тетерин С.В. & 12 & 1,55 \\
\hline 32 & ООО «Уралавто» & 4 & 0,52 \\
\hline 33 & ИП Фадеев С.М. & 7 & 0,90 \\
\hline 34 & ИП Фофанов С.А. & 6 & 0,78 \\
\hline 35 & ИП Целоусов А.А. & 8 & 1,03 \\
\hline 36 & ИП Черноколпаков Д.С. & 7 & 0,90 \\
\hline 37 & ИП Шушлебин В.И. & 2 & 0,26 \\
\hline 38 & МУП «ПермГорЭлектроТранс» & 8 & 1,03 \\
\hline & Итого & 774 & 100 \\
\hline
\end{tabular}




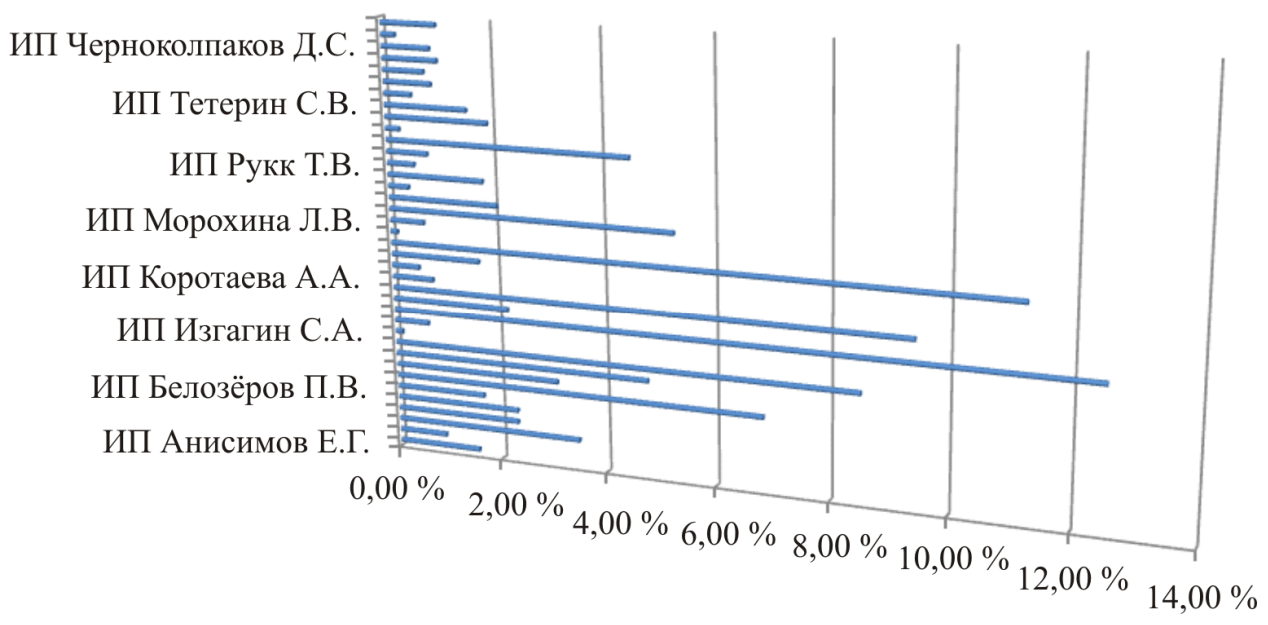

Рис. Структура рынка автобусного транспорта Перми

(в процентах от общей суммы графиков буднего дня)

В отношении представителей частного сектора, обслуживающих городские автобусные маршруты, органы МСУ Перми также реализуют различные стратегии, основания которых можно обозначить понятиями «свои - все остальные». При этом, если отношения администрации и муниципальных перевозчиков строятся на «формальной принадлежности» последних к власти, то в данном случае основу взаимодействия составляет «неформальная близость» к органам МСУ. Возможности для достижения неформальных договоренностей и получения преимуществ имеют перевозчики, находящиеся в «особых» отношениях с отдельными депутатами Пермской городской думы, сотрудниками местной администрации.

К примеру, показательна в этом смысле многоаспектная деятельность одного из депутатов Пермской городской думы VI созыва, члена конкурсной комиссии по проведению конкурсов на право заключения договоров на осуществление пассажирских перевозок автомобильным транспортом на маршрутах регулярных перевозок Перми [11]. Он владел ООО «Эдельвейс», который с 2006 года обслуживал нелегальный маршрут № 100 сообщением «м/p Садовый - м/p Парковый». В 2009 году деятельность этого маршрута была прекращена и легализована в маршруте № 67, обслуживаемом ООО «Пермский экспресс» до случая с «бешеным автобусом» (этот автобус принадлежал депутату и был в плачевном состоянии) [12]. В настоящее время под различными ООО перевозчик обслуживает маршруты Кировского района. Автобусы этого перевозчика по факту полностью соответствуют условиям конкурса (год выпуска, низкопольность, нормы экологичности). Однако за ними отсутствует какой-либо контроль со стороны органов власти. С негативными последствиями этого сталкиваются пассажиры. Так, они отмечают случаи возникновения мелких неисправностей (к примеру, у автобуса МАЗ - маршрут № 80 - 
на Красавинском мосту отлетел люк; на ул. Стахановской в связи с постоянной переполненностью автобусов отпала дверь у НефАЗа), а также несоблюдение перевозчиком расписания движения.

В ходе внедрения новой Единой маршрутной сети в 2015 году поэтапно были проведены конкурсы на обслуживание автобусных маршрутов. Среди основных критериев конкурса: год выпуска, низкопольность, соответствие двигателя нормам Евро-3 и выше, использование экологичного топлива (например, метанового). Результаты некоторых конкурсов представляются парадоксальными, когда конкурс на маршрут выигрывает одна организация, а обслуживает прежняя. К примеру, маршрут №1 (м/p Садовый - станция Пермь II) был выигран ИП Златковская Т.А. [13]. Однако на линии остались 2 прежних перевозчика ООО «Техстрой-Авто» (директор Бабушкин М.Н) и ООО «СпецТрансАвто» (в ведении Жуланова С.В.), и также, в нарушение формальных правил, один график получил ООО «ГорАвтоТранс».

Аналогичная ситуация сложилась при определении перевозчика на обслуживание маршрута №68. Конкурс выиграла ИП Златковская Т.А., однако на данном маршруте продолжили работу другие предприниматели из «Единого союза перевозчиков».

Показателен пример функционирования автобусного маршрута № 14, в конкурсе на распределение которого выиграл ИП Колесников И.А. Однако он получил на нем лишь 5 графиков, основным перевозчиком на этом маршруте остался ИП Новоселов О.В., который участвовал в конкурсе, но проиграл его по причине отсутствия необходимого количества новых автобусов.

Интересная ситуация наблюдается с одним из самых рентабельных маршрутов Перми - № 27. Большую часть графиков обслуживает ООО «Вираж», которое заняло в конкурсе 6-е место в связи с отсутствием новых автобусов [14]. Аналогичных примеров в городе множество.

В этой связи под сомнение ставится объективность результатов проводимых администрацией Перми конкурсов на распределение автобусных маршрутов. С одной стороны, маршруты обслуживаются лицами, проигравшими конкурсы. С другой, в ряде случаев конкурс выигрывает перевозчик, подвижной состав которого не соответствует конкурсным требованиям.

Причины возникновения подобных ситуаций могут выражаться в неформальных договоренностях некоторых перевозчиков с органами МСУ Перми. Отметим, помимо результатов конкурсов это касается также изменения самих маршрутов ${ }^{5}$.

${ }^{5}$ К примеру, автобусный маршрут № 8, следуя от Центрального рынка в соответствии с Единой маршрутной сетью не останавливается на остановке «Драмтеатр», а сразу с улицы Борчанинова поворачивает на улицу Петропавловскую. Выгоды в данном случае имеет перевозчик, обслуживающий одновременно с маршрутом № 8 маршруты № 15 и 20, которые осуществляют посадку пассажиров на остановке «Драмтеатр». 
Как показывают результаты исследования, перевозчики, в отношении которых органы МСУ реализуют стратегии лояльности (обслуживают маршрут, проиграв конкурс либо не участвуя в нем; выигрывают конкурсы, не соответствуя требованиям; осуществляют деятельность вне контроля со стороны местных властей) занимают значительные доли рынка автобусного транспорта Перми (ИП Караев С.Н., ИП Колодяжный А.П., ИП Богданов А.В., ИП Новоселов О.В.).

Заключение. Проведенное авторами исследование взаимодействий органов МСУ Перми и перевозчиков позволяет сделать следующие выводы. Определив в качестве приоритета в сфере общественного транспорта электрический транспорт, обслуживаемый МУП «ПермГорЭлектроТранс», местная администрация реализует по отношению к нему стратегию «покровительства». Во-первых, установленные городскими властями формальные «правила игры» на рынке пассажирских перевозок (требования к характеристикам подвижного состава, соблюдение графиков и т.д.) оборачиваются их нарушением со стороны МУП «ПермГорЭлектроТранс» с молчаливого согласия органов МСУ. МУП «ПермГорЭлектроТранс» является частым нарушителем графиков движения (особенно в часы пик и в вечернее время), имеет устаревший троллейбусный и трамвайный парки, при этом никаких санкций со стороны органов МСУ Перми в отношении нарушителя не применяется. В данном случае, по мнению авторов, важным будет увеличение штрафов в отношении нарушителя.

Во-вторых, несмотря на то, что большинство жителей города предпочитает автобусный транспорт (83 \%), муниципалитет выделяет значительный объем субсидий МУП «ПермГорЭлектроТранс», маршруты которого в меньшей степени востребованы жителями города (17\%). Муниципальная власть не осуществляет должного контроля за расходованием средств МУП «ПермГорЭлектроТранс». Кроме того, СМИ фиксируют ухудшение финансового положения МУП «ПермГорЭлектроТранс» и растущую налоговую задолженность предприятия [15]. При этом в условиях изменения порядка предоставления субсидий юридическим лицам (в соответствии с вступившим в силу в сентябре 2016 года Постановлением Правительства РФ № 887) муниципалитет не сможет предоставлять субсидии предприятиям, имеющим задолженность перед налоговыми органами. Закономерно встает вопрос о разработке дополнительных мер по решению финансовых проблем предприятия. По мнению авторов, с целью повышения эффективности расходования бюджетных средств МУП «ПермГорЭлектроТранс» необходимо ввести отчетность о проводимых мероприятиях и объемах средств, затраченных на ремонт трамвайных путей и переездов, замену бетонных плит, плановый ремонт электроинфраструктуры и т.д.

В-третьих, что касается финансового взаимодействия органов МСУ Перми и частных перевозчиков на автобусных маршрутах, выплата субсидий последним за провоз льготных категорий граждан не всегда осуществляется своевременно и в полном объеме. В целях достижения прозрачности в осу- 
ществлении выплат субсидий необходимо выкладывать в открытый доступ информацию о количестве перевозимых перевозчиком пассажиров (оплачивающих проезд наличными; льготные категории населения, использующие проездные документы; расплачивающихся электронной картой проезда) и данные о количестве перечисленных перевозчику субсидий за каждую категорию пассажиров. В Перми запущена автоматизированная система оплаты проезда - электронный проездной («один билет»). Она внедрена только на $45 \%$ автобусных маршрутов. В электротранспорте оплата с помощью карт на данный момент не осуществляется вовсе. По мнению авторов, необходимо увеличить количество транспортных средств, принимающих электронные карты проезда. Этот способ будет способствовать установлению прозрачности в вопросе осуществления выплат перевозчикам.

В-четвертых, нарушение администрацией Перми формальных «правил игры» в сфере общественного транспорта отмечается и при взаимодействии с некоторыми частными перевозчиками. В отношении последних органы МСУ peaлизуют стратегии лояльности. Обслуживание некоторыми частными перевозчиками автобусных маршрутов противоречит результатам конкурсов, проведение которых прежде всего требует повышения прозрачности за счет размещения в свободном доступе информации о перевозчиках, подавших заявку на обслуживание маршрута (к примеру, о подвижном составе перевозчика).

Таким образом, как показали результаты исследования, в отношении муниципальных перевозчиков (МУП «ПермГорЭлектроТранс») органы власти Перми реализуют стратегии «покровительства», что закономерно вызывает несогласие «частников». Общую волну недовольства позволяет смягчить избирательное отношение органов МСУ к представителям «частного сектора». Неформальные практики взаимодействия городских властей и отдельных перевозчиков, обслуживающих автобусные маршруты, в ряде случаев подменяют формальные институты и вступают с ними в противоречие.

\section{Список литературы}

1. Об утверждении Единой сети регулярных городских маршрутов пассажирского транспорта города Перми [Электронный ресурс]: Постановление администрации г. Перми от 30.01.2004 № 264 (ред. от 28.05.2004). - URL: http://perm.news-city.info/docs/sistemst/dok_oeryhz.htm (дата обращения: 29.06.2016).

2. Об утверждении Единой сети маршрутов регулярных перевозок пассажирского транспорта общего пользования города Перми [Электронный ресурс]: Постановление администрации г. Перми от 04.06.2006 №1148. - URL: http://permkrai.info/2006/07/04/p38435.htm (дата обращения: 29.06.2016).

3. Пелявина И. Горадминистрация распрягает автобусы [Электронный peсурс] // Коммерсант-Прикамье. - 2006. - 16 мая. - URL: http://www.kommersant.ru/doc-rss/673456 (дата обращения: 29.06.2016). 
4. Нода А. Нет диктату перевозчиков [Электронный ресурс] // Социологическое ведомство оперативных исследований. - URL: http://svoi.org/index.php?newsid=599 (дата обращения: 29.06.2016).

5. Об утверждении Единой маршрутной сети городского пассажирского транспорта города Перми [Электронный ресурс]: Постановление администрации г. Перми от 30.10 .2014 № 796 (с изм. на 21.05.2015). - URL: http://docs.cntd.ru/document/428689200 (дата обращения: 29.06.2016).

6. Пояснения к Единой маршрутной сети // Сайт администрации города Перми. - URL: http://www.gorodperm.ru/upload/news/Pojasnenija_k_JEMS.docx (дата обращения: 29.06.2016).

7. Значимые даты в истории предприятия // Сайт МУП «ПермГорЭлектроТранс». - URL: http://permget.ru/company/ (дата обращения 01.07.2016).

8. «Пермгорэлектротранс» получит 216,9 млн рублей из городского бюджета [Электронный ресурс] // Business-class. - 2015. - 28 апр. - URL: http://www.business-class.su/news/2015/04/28/permgorelektrotrans-poluchit-2169mln-rubley-iz-gorodskogo-byudzheta (дата обращения: 29.06.2016).

9. Пелявина И. Воспринимают как должное [Электронный ресурс] // Коммерсант-Прикамье. - 2016. - 23 янв. - URL: http://www.kommersant.ru/ doc/2899686 (дата обращения: 29.06.2016).

10. Свизева В. Пермские перевозчики на грани банкротства [Электронный ресурс] // Интернет-портал 59. ru. - 2015. - 13 нояб. - URL: http://59.ru/ text/problem/99962495160320.html (дата обращения: 29.06.2016).

11. Никитин Д.С. «Горсвета» сживут [Электронный ресурс] // Коммерсант-Прикамье. - 2015. - 23 июля. - URL: http://www.kommersant.ru/ doc/2773803 (дата обращения: 01.07.2016).

12. Мучкина Т. Бешеный автобус задавил веру в справедливость [Электронный ресурс] // Аргументы и факты. - 2011. - 26 мая. - URL: http://www.perm.aif.ru/gorod/infrastructure/120849 (дата обращения: 01.07.2016).

13. Протокол заседания конкурсной комиссии по проведению конкурсов на право заключения договоров на осуществление пассажирских перевозок автомобильным транспортом на маршрутах регулярных перевозок города Перми [Электронный pecypc]. - URL: http://www.gorodperm.ru/upload/ pages/11692/dat_1430296147459.doc (дата обращения: 30.06.2016).

14. Стерлягов А., Григорьев В. А вас попрошу расстаться. Прокуратура Перми предложила мэрии расторгнуть договоры с тремя перевозчиками из-за поддельных документов [Электронный ресурс] // Business-class. - 2016. 10 нояб. - URL: http://www.business-class.su/news/2016/02/20/a-vas-poproshurasstatsya (дата обращения: 30.06.2016).

15. Пелявина И., Суханов В. Налогооблагаемая фаза. «Пермгорэлектротранс» может оказаться в сложной финансовой ситуации [Электронный pecypc] // Коммерсант-Прикамье. - 2016. - 8 нояб. - URL: http://www.kommersant.ru/doc/3136377 (дата обращения: 09.11.2016).

PNRPU Sociology and Economics Bulletin. 2017. No. 2 


\section{References}

1. Ob utverzhdenii edinoi seti reguliarnykh gorodskikh marshrutov passazhirskogo transporta goroda Permi [On approval of a unified route network of regular intracity lines for passenger transport in the city of Perm]. Postanovlenie Administratsii g. Permi ot 30.01.2004 № 264 (red. ot 28.05.2004) [Decree of the Administration of Perm of 30 Jan., 2004 no. 264 (as amended on May 28, 2004)]. Available at: http://perm.news-city.info/ docs/sistemst/dok_oeryhz.htm (accessed 29 June 2016).

2. Ob utverzhdenii Edinoi seti marshrutov reguliarnykh perevozok passazhirskogo transporta obshchego pol'zovaniia goroda Permi [On approval of a unified route network for regular public passenger transport of the city of Perm]. Postanovlenie Administratsii g. Permi ot 04.06.2006 №1148 [Decree of the Administration of Perm of 04 Apr., 2006 no. 1148]. Available at: http://permkrai.info/ 2006/07/04/p38435.htm (accessed 29 June 2016).

3. Peliavina I. Goradministratsiia raspriagaet avtobusy [The city administration unharness the buses]. Kommersant-Prikam'e, 16 May, 2006. Available at: http://www.kommersant.ru/doc-rss/673456 (accessed 29 June 2016).

4. Noda A. Net diktatu perevozchikov [No to carriers dictate]. Sotsiologicheskoe vedomstvo operativnykh issledovanii. Available at: http://svoi.org/index.php?newsid=599 (accessed 29 June 2016).

5. Ob utverzhdenii edinoi marshrutnoi seti gorodskogo passazhirskogo transporta goroda Permi [On approval of a unified route network of urban passenger transport in the city of Perm]. Postanovlenie Administratsii g. Permi ot 30 Oct. 2014 no. 796 (s izmeneniiami na 21.05.2015). [Decree of the Administration of Perm of 30 October 2014 no. 796 (as amended on 21 May, 2015)]. Available at: http://docs.cntd.ru/document/428689200 (accessed 29 June 2016).

6. Poiasneniia $\mathrm{k}$ Edinoi marshrutnoi seti [Explanations to the Unified route network]. Sait administratsii goroda Permi. Available at: http://www.gorodperm.ru/upload/news/Pojasnenija_k_JEMS.docx (accessed 29 June 2016).

7. Znachimye daty $\mathrm{v}$ istorii predpriiatiia [Significant dates in the history of the company]. Sait MUP «PermGorElektroTrans». Available at: http://permget.ru/ company/ (accessed 01 July 2016).

8. «Permgorelektrotrans» poluchit $216,9 \mathrm{mln}$ rublei iz gorodskogo biudzheta [Permgorelectrotrans to receive 216.9 million rubles from the city budget]. Business-class, 28 April 2015. Available at: http://www.business-class.su/news/ 2015/04/28/permgorelektrotrans-poluchit-2169-mln-rubley-iz-gorodskogobyudzheta (accessed 29 June 2016).

9. Peliavina I. Vosprinimaiut kak dolzhnoe [Perceived as a matter of course]. Kommersant-Prikam'e, 23 Jan. 2016. Available at: http://www.kommersant.ru/ doc/2899686 (accessed 29 June 2016). 
10. Svizeva V. Permskie perevozchiki na grani bankrotstva [Perm carriers on the verge of bankruptcy]. Internet-portal 59.ru, 13 Nov. 2015. Available at: http://59.ru/text/problem/99962495160320.html (accessed 29 June 2016).

11. Nikitin D.S. S "Gorsveta" szhivut [Hounded to death in "Gorsvet"]. Kommersant-Prikam'e, 23 July, 2015. Available at: http://www.kommersant.ru/ doc/2773803 (accessed 01 July 2016).

12. Muchkina T. Beshenyi avtobus zadavil veru v spravedlivost' [Raging bus crushes faith in justice]. Argumenty $i$ fakty, 26 May 2011. Available at: http://www.perm.aif.ru/gorod/infrastructure/120849 (accessed 01 July 2016).

13. Protokol zasedaniia konkursnoi komissii po provedeniiu konkursov na pravo zakliucheniia dogovorov na osushchestvlenie passazhirskikh perevozok avtomobil'nym transportom na marshrutakh reguliarnykh perevozok goroda Permi [Minutes of the contest committee meeting for holding competitive tenders for the right to conclude contracts for the implementation of passenger transportation by motor transport on the regular transport routes of Perm city]. Available at: http://www.gorodperm.ru/upload/pa-ges/11692/dat_1430296147459.doc (accessed 30 June 2016).

14. Sterliagov A.M., Grigor'ev V. A vas poproshu rasstat'sia. Prokuratura Permi predlozhila merii rastorgnut' dogovory $\mathrm{s}$ tremia perevozchikami iz-za poddel'nykh dokumentov [I am asking you to part. Perm prosecutor's office suggested the mayor's office to terminate contracts with three carriers because of the documents forged]. Business-class, 10 November 2016. Available at: http://www.business-class.su/news/2016/ 02/20/a-vas-poproshu-rasstatsya (accessed 30 June 2016).

15. Peliavina I., Sukhanov V. Nalogooblagaemaia faza. "Permgorelektrotrans" mozhet okazat'sia $\mathrm{v}$ slozhnoi finansovoi situatsii [The taxable phase. Permgorelectrotrans may find itself in a difficult financial situation]. KommersantPrikam'e, 8 November 2016. Available at: http://www.kommersant.ru/doc/3136377 (accessed 09 November 2016).

Оригинальность статьи - $94 \%$

Получено 24.11.2016

PNRPU Sociology and Economics Bulletin. 2017. No. 2 
A.S. Zuykina, Yu.G. Shilov

\section{STRATEGIES DIFFERENTIATION OF LOCAL AUTHORITIES IN PERM TOWARDS MUNICIPAL TRANSPORT OPERATORS}

The article examines the interactions between local authorities in Perm and municipal transport operators serving the intracity routes. The functions of local authorities in this field include defining the route and schedule, as well as notification about the changes. Other functions include holding competitive tenders on routine maintenance and subsidizing the operators' work. In this respect, the difference in the attitude towards municipal and private carriers appears explicable. Thus, the former are often given financial aid, while the latter take part in competitive tenders. The first part of the article is devoted to the background of municipal politics development in the sphere of transport in Perm in the early 2000s. Before that time the city had a route network established in the Soviet period. It was not until 2004 that the network was renovated and substituted by the single network of regular intracity routes. The modernization of transport was characterized by the actual liquidation of a municipal bus fleet and the implementation of competitive tenders for the right of intracity routes service. As a consequence, it led to the increase in the number of participants from private carriers. The authors aim to define the specificity of local authorities' strategies concerning both private and municipal carriers, as well as certain private sector representatives. Based on the research findings, the authors point out that the formal cooperation institutions are often substituted by the informal agreements and practices. The empirical data of the research include the local media materials, as well as the statistical evidence on various parameters of private carriers servicing the intracity routes of Perm.

Keywords: local authorities, public transport, municipal carriers, private carriers, municipal authorities' strategies towards carriers.

Anna S. Zuykina - Candidate of Political Sciences, Associate Professor, Dept. of State Administration and History, Perm National Research Polytechnic University, e-mail: votinova@inbox.ru.

Yury G. Shilov - Bachelor of State Administration and History, Perm National Research Polytechnic University, e-mail: yury.schilov2014@yandex.ru. 